\title{
REVIEW
}

\section{The culprit behind amyloid beta peptide related neurotoxicity in Alzheimer's disease: oligomer size or conformation?}

\author{
Kerensa Broersen, Frederic Rousseau and Joost Schymkowitz*
}

\begin{abstract}
Since the reformulation of the amyloid cascade hypothesis to focus on oligomeric aggregates of amyloid beta as the prime toxic species causing Alzheimer's disease, many researchers refocused on detecting a specific molecular assembly of defined size that is the main trigger of Alzheimer's disease. The result has been the identification of a host of molecular assemblies containing from two up to a hundred molecules of the amyloid beta peptide, which were all found to impair memory formation in mice. This clearly demonstrates that size is insufficient to define toxicity and peptide conformation has to be taken into account. In this review we discuss the interplay between oligomer size and peptide conformation as the key determinants of the neurotoxicity of the amyloid beta peptide.
\end{abstract}

\section{Introduction}

The original amyloid cascade hypothesis for Alzheimer's disease (AD) [1] has recently been reformulated to focus on soluble aggregates as the pathogenic molecular form of the amyloid beta peptide (A $\beta$ ) [2] (Figure 1). $A \beta$ is naturally present in the brain and cerebrospinal fluid of humans throughout life [3]. Its role is currently unknown. The mere presence of $A \beta$ in the brain is not sufficient to cause symptoms of neurodegeneration. It has been recognized previously that neuronal injury is rather the result of ordered $A \beta$ self-association [4]. The amyloid plaques found in $A D$ patient brains, which serve as a hallmark for $\mathrm{AD}$, have been found to contain vast amounts of $A \beta$ organized into amyloid fibrils. There is no clear correlation, however, between the presence of the

*Correspondence: joost.schymkowitz@switch.vib-vub.be

Switch Laboratory, Flanders Institute for Biotechnology (VIB) and Vrije Universiteit Brussel (VUB), Pleinlaan 2, Brussels 1050, Belgium
$A \beta$ containing plaques in the brain and the severity of the neurodegenerative symptoms observed in $\mathrm{AD}$ patients [5]. Therefore, the focus of research in this area has shifted from senile plaques toward soluble oligomeric conformations of $A \beta$ as the toxic species as these strongly correlate with the severity of dementia $[2,6,7]$. This oligomeric form of $A \beta$ is highly toxic to the brain and is the trigger for loss of synapses and neuronal damage $[8,9]$. Because of this, many laboratories have been hunting for a specific molecular assembly of defined size that is the main trigger of $\mathrm{AD}$. The result has been the identification of a host of molecular species of $A \beta$, ranging from dimers [10-12], trimers [13] and $A \beta$ species with a molecular weight of $56 \mathrm{kDa}$ [14] to $A \beta$-derived diffusible ligands (ADDLs) [15,16] and protofibrils [17] in potent neurotoxic fractions. All are capable of impairing memory formation in mice and their formation and significant accumulation in the brain should thus be considered a potential cause of AD.

Recent in vitro studies of the amyloid formation of $\mathrm{A} \beta$ demonstrate that the species mentioned all occur but that they are only transiently populated [18-21]. Moreover, their isolation and characterization are hampered by solvent extraction procedures and detection methods $[22,23]$, making it difficult to study them in detail. However, looking at the studies available, a hypothesis can be formed that the key determinant for the neurotoxicity of $A \beta$ not only involves the degree of oligomerization, but also the specific structural conformation of peptides in the assembly. This concept reconciles the apparently contradictory results that widely differing preparations of $A \beta$ exert similar cytotoxic effects, and offers the therapeutic potential for targeting the key conformation with small molecules or monoclonal antibodies. This review will discuss the degree to which a specific conformation rather than a specific oligomer size may act as the key determinant of development of AD.

\section{The aggregation pathway of $\mathbf{A} \boldsymbol{\beta}$}

Since the establishment of the amyloid cascade hypothesis, significant research effort has been focused on the 


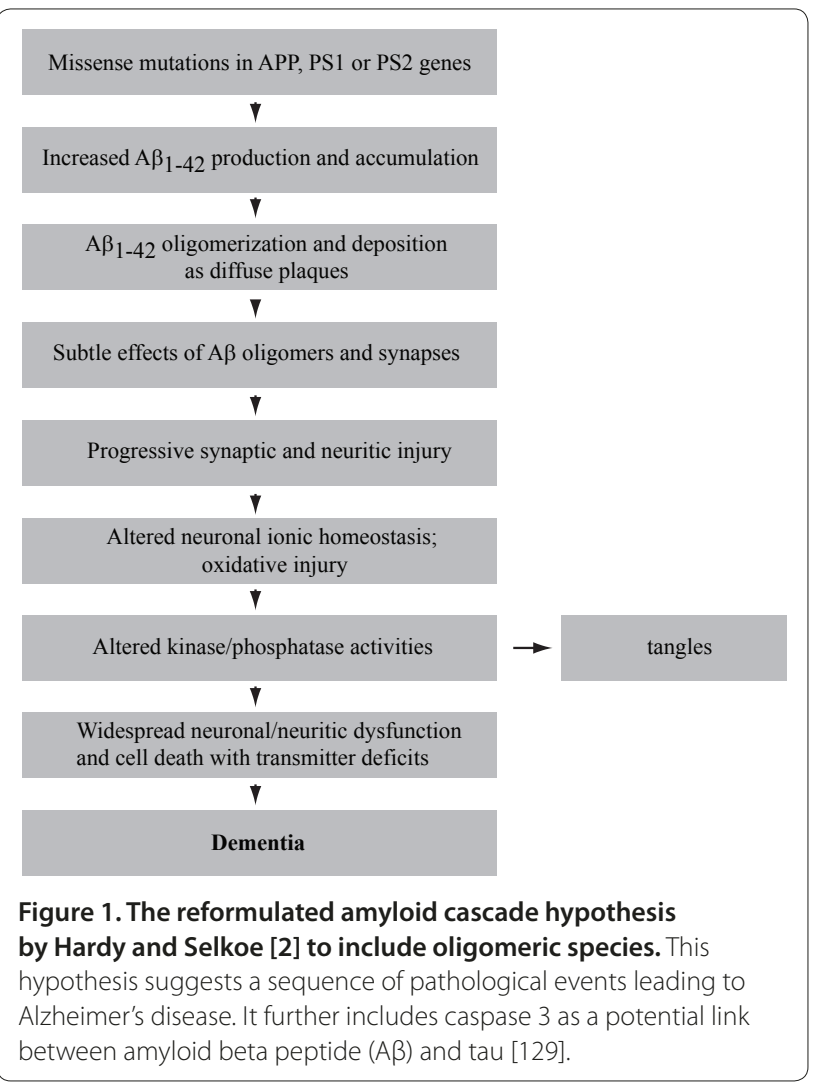

identification of specific $A \beta$ species in the brain that could be related to $\mathrm{AD}$. In spite of this, it remains unclear exactly what happens to $A \beta$ in vivo after it is cleaved from the amyloid precursor protein by $\gamma$-secretase. It is known that the carboxy-terminal heterogeneity generated by $\gamma$-secretase may be an important contributing factor since in vitro preparations of the two major peptide fragments generated, $A \beta_{1-42}$ and $A \beta_{1-40}$, display a marked difference in neurotoxicity by a range of biophysical assays and this correlates with a clear difference in aggregation behavior [24]. For example, samples of synthetic $A \beta_{1-40}$ primarily exist in vitro as a monomer/dimer mixture, whilst from the time of preparation (time zero) samples of $A \beta_{1-42}$ also contain a range of other low-order oligomeric species [7].

The assembly of mature $A \beta$ amyloid fibrils is generally described as a nucleation-dependent polymerization reaction. Like any chemical process, the characterization of this assembly process requires the description of the order in which the relevant molecular species occur along the reaction pathway. However, as aggregation is a stochastic process, molecules will not synchronize during the reaction and, as a result, the reaction mixture will be highly complex and composed of several species at any given time. Homogeneity of the sample is not thought to occur until after the polymerization reaction is complete and even then it is possible that the formed mature fibrils or plaques are not eternally stable. To make matters worse, the composition of the reaction will be significantly modulated by peptide concentration and physicochemical parameters, such as temperature, ionic strength and $\mathrm{pH}$. It is thus not surprising that independent studies of this highly dynamic reaction mixture have yielded a plethora of transient molecular species that have been claimed to occupy an essential position along this pathway. The transient nature of the intermediate oligomers is equally challenging for the characterization of the toxic potential of these species [25], and thus a number of differently sized oligomers have been suggested as the cause of AD (reviewed in [26-28]).

In general terms, the kinetics of fibril formation by $A \beta$, as well as many other disease-related and synthetic amyloidogenic peptides, consists of a lag phase, during which a thermodynamically stable nucleus needs to accumulate, which is then followed by a rapid elongation phase that sees the formation of mature amyloid fibrils [29]. However, on a structural level there is significant debate over which conformational changes are essential for the timing of the reaction. Most proposed pathways for the initial stages of $A \beta$ amyloid fibril formation amount to a sequence of events that can be summarized as follows: unordered monomeric $A \beta$ in solution converts into an 'activated' monomer that then recruits other $A \beta$ molecules to form low- $n$ oligomers [30].

Several studies proposed that monomeric $A \beta$ in solution exists in an equilibrium between an $\alpha$-helical and a $\beta$-sheet conformation (step I in Figure 2) and from this mixture only the $\beta$-sheet conformer can accommodate the formation of low molecular weight, $\beta$-sheetenriched oligomers (step II in Figure 2) [31,32]. In sharp contrast, other reports suggest that the conformation of $\mathrm{A} \beta$ in the activated monomeric state involves $\alpha$-helical components [33]. Interestingly, the ambiguity between $\alpha$ helical and $\beta$-sheet propensities is a sufficiently frequently occurring feature of amyloid forming sequences that it can be employed to identify such sequences $[34,35]$. Moreover, helix-helix associations have been proposed to constitute the major mode of early associations between proteins en route to amyloid formation. Apart from $A \beta$, other well-known examples displaying similar characteristics include islet amyloid polypeptide, $\alpha$-synuclein and calcitonin [33]. This helix association pathway would require an as yet undefined rearrangement of the initial helical species into a $\beta$-sheet conformation, but is supported by a range of nuclear magnetic resonance (NMR) studies of the solution structure of $A \beta$ that report an $\alpha$ helical structure for the monomeric peptide.

It has to be noted that most of these studies were done in the presence of organic solvents and detergents that were intended to reduce the peptide's aggregation rate sufficiently to allow the recording of NMR spectra. 


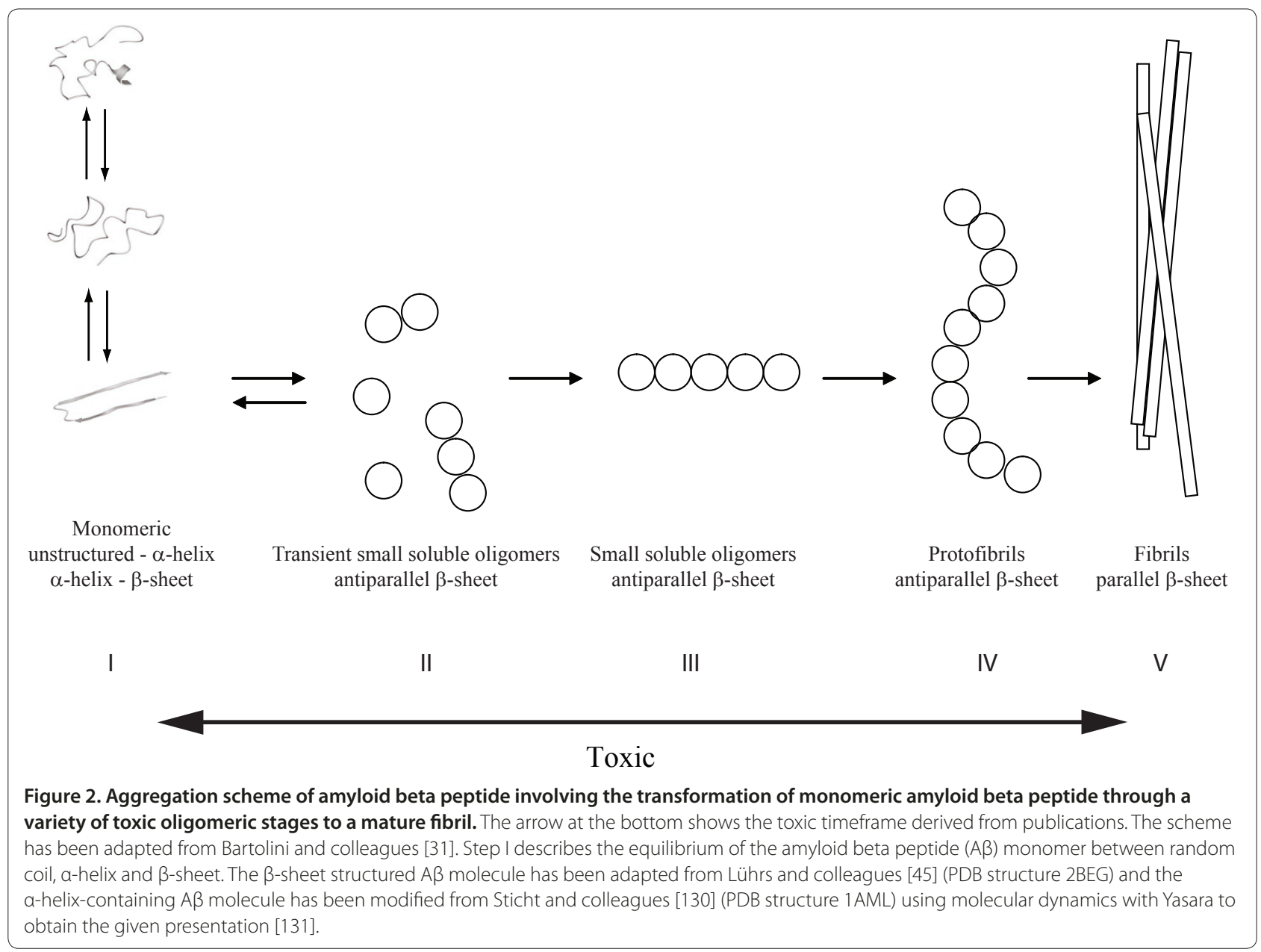

Interestingly, several studies of the conformations of $A \beta$ in the presence of lipid membranes have reported increases in both $\alpha$-helical [36] and $\beta$-sheet structures [37]. It is generally known that some detergents and organic solvents can induce secondary structure in proteins, particularly $\alpha$-helical structure (reviewed in [38]). Yet, two carefully conducted studies employing solution NMR and molecular dynamics without the use of organic co-solvents and detergents failed to detect significant $\alpha$-helical stabilization for $\mathrm{A} \beta[39,40]$.

Whether significant stabilization and population of such an intermediate is indeed required to trigger toxic oligomer formation can be debated. To illustrate this, it has been shown for both HypF-N and human lysozyme that aggregation can be initiated by a population of less than $1 \%$ of a specific partially folded conformation [41,42]. Small and only transiently populated conformations hence could provide the key to toxic oligomer formation. Nevertheless, the conflicting nature of published reports on the conformational bias in monomeric $A \beta$ suggests several aggregation-prone conformations may coexist and that environment heavily influences the route taken by most of these molecules. Moreover, post-translational modifications and the terminal heterogeneity that characterizes $\mathrm{A} \beta$ in vivo may play a dominant role.

Whatever the conformations that drive the initial associations of $A \beta$ peptides, the resulting low- $n$ oligomers seem to be consistently enriched in $\beta$-sheet structures, although the topology of the strands remains unresolved: some groups report that oligomers contain exclusively antiparallel $\beta$-sheet structure (step III in Figure 2) [43], whereas others suggest a mixture of antiparallel and parallel $\beta$-sheets [44]. Structural investigation of the $A \beta$ aggregation pathway has suggested that antiparallel structures need to convert to a parallel topology in order to allow formation of the so-called protofibrillar state of $A \beta$ (step IV in Figure 2), which is the individual building block of the amyloid fibrils and is thought to consist of a single array of peptides in a parallel $\beta$-sheet like conformation [11].

The length-wise association of individual protofibrils produces the mature amyloid fibrils, whose structure has been studied in most detail due to their high stability under a wide range of physicochemical conditions (step 
$\mathrm{V}$ in Figure 2). For example, a model of $A \beta$ amyloid fibrils derived using solution NMR with hydrogen-deuterium exchange and mutagenesis suggests that residues 18 to 42 stack as $\beta$-hairpin-like structures along the fiber axis [45]. Although there is an ongoing debate on the exact involvement of particular residues in this arrangement (in particular the location of the loop), there seems to be general agreement that the amyloid fibrils that accumulate in plaques found in the brains of patients with $\mathrm{AD}$ are stabilized by a backbone of two intermolecular parallel $\beta$-sheets connected by a loop region [46].

In Figure 2, we show a schematic outline of the current known aspects of the fibrillation mechanism of $A \beta$, based on a recently published scheme by Bartolini and colleagues [31]. It remains unclear how oligomer size corresponds to conformational reorganization or how oligomer size and conformation combine to yield a toxicity response.

\section{Does the size of $A \beta$ oligomers determine neurotoxicity?}

The search for an $A \beta$ species that is capable of causing cognitive disorder as observed in $\mathrm{AD}$ patients led to several reports of animal-cell derived $[13,47,48]$, humanderived [10] and synthetically prepared [9,49-52] oligomers that have been found to induce disruptions of synaptic activity in vitro or impair cognitive function in animal models. For extensive reviews on these species see $[26,27,53]$.

\section{Monomeric and fibrillar $A \beta$}

Monomeric forms of $A \beta$ have frequently been proposed as toxic modulators in the development of AD. For example, Taylor and colleagues [30] reported that maximum cell damage observed in SH-EP1 cells and hippocampal neurons using a SYTOX Green assay coincides with the accumulation of a monomeric $A \beta$ species able to multimerize into higher- $n A \beta$ species, also called 'activated monomer'. Similarly, mature A $\beta$ fibrils have been suggested as potent neurotoxic AD-inducers, although with similar inconsistent findings as for monomeric $A \beta$. The hypothesis that not all fibril morphologies are equally toxic, leading to variable results with regard to cytotoxicity, was successfully challenged by Yoshiike and colleagues [54]. They reported that, using point mutations and chemical modification, both a $\beta$-sheet fibrillar structure as well as the surface physicochemical composition of the fibril define the toxic potency of $A \beta$. One year earlier, Puzzo and Arancio [55] had shown that synthetically derived fibrillar $A \beta$ can impair the late phase of long-term potentiation. As it is very difficult to ensure the purity of a monomeric or fibrillar $\mathrm{A} \beta$ solution, without contamination of either preseeds or protofibrillar material, it can not be excluded that the toxicity observed for monomeric and fibrillar $A \beta$ is actually the result of contamination. Moreover, increasing evidence suggests that the toxicity of $A \beta$ originates instead from oligomeric $A \beta$, for which reason this review will further focus on the role of oligomeric $\mathrm{A} \beta$ in the development of $\mathrm{AD}$.

\section{The synaptotoxic SDS-stable dimer}

In 2008, the Walsh lab identified an enrichment of sodium dodecyl sulfate (SDS)-stable $\mathrm{A} \beta$ dimers in both human $\mathrm{AD}$ patients and rat cerebrospinal fluid (CSF) [10] that activate glial cells and can lead to nerve cell death in cultures containing astrocytes [56]. Injection of human CSF containing $A \beta$ dimers but not higher- $n A \beta$ oligomers into animals showed a complete abolishment of long-term potentiation (Figure 3e); this adverse effect could be reversed by the systemic infusion of the synthetically derived anti-A $\beta_{1-40}$ polyclonal antibody R1282. CSF samples that contained only $A \beta$ monomer and no detectable dimer did not inhibit long-term potentiation. At this time it was also recognized that the isolation of large quantities of the SDS-stable dimer from human CSF was difficult, and a synthetic, disulfide stabilized $A \beta$ dimer $\left(\mathrm{A} \beta_{1-40}\right.$ Ser26Cys) was prepared [57] and used to further explore any detrimental effects of $A \beta$ dimers on synaptic activity [11]. Later studies [12] used a combined approach of immunoblotting and western blotting techniques to study the A $\beta$ population in J20 mice carrying Swedish and Indiana mutations in amyloid precursor protein. These studies showed that before SDS-stable dimers can be detected, Tris-buffered saline and triton-insoluble $A \beta$ aggregates are present, suggesting that the assembly of $A \beta$ species throughout life is dynamic and heterogeneous. The authors further concluded that it would be difficult to attribute synaptotoxicity to one single $A \beta$ species.

\section{Toxic $A \beta^{*} 56$}

In 2006, the Ashe lab reported that the presence of an extracellular, soluble $A \beta_{1-42}$ species with a molecular weight of $56 \mathrm{kDa}(\mathrm{A} \beta * 56)$ coincides with memory loss of $\operatorname{Tg} 2576$ mice and that administration of an isolated fraction of $A \beta$ of this molecular weight induced similar memory loss in young rats [14] (Figure 3c). Interestingly, this much larger $56 \mathrm{kDa}$ species results in a similar ADlike phenotype to that occurring with the dimer described by the Walsh lab, suggesting that AD-related toxicity is extended over a very wide range of $A \beta$ oligomer sizes. A recently published work systematically comparing the effects of brain- or cell-derived $A \beta$ assemblies with synthetic preparations further corroborated a concentration-dependent detrimental effect of $A \beta * 56$ oligomers on cognition in rats [58].

\section{Lipid-dissociated mature fibrils}

In 2008, work by our own group suggested that mature fibrils may not be the inert end-products of a pathway 
A

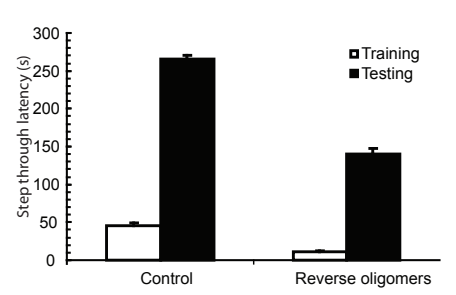

B

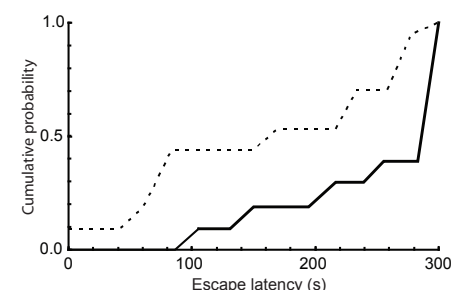

C

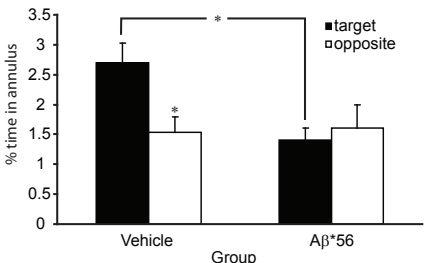

D

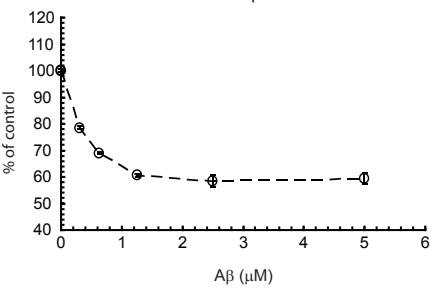

E

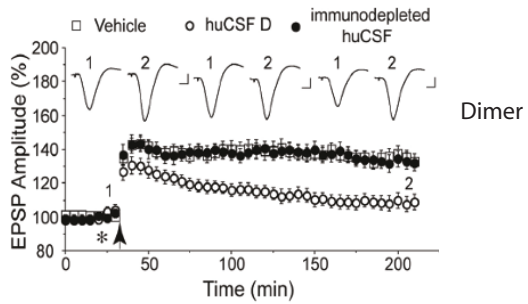

Molecular

weight

80-500 kDa

Lipid induced

oligomers

$->100 \mathrm{kDa}$

ADDLs

$17-42 \mathrm{kDa}$

$-8.8 \mathrm{kDa}$

Figure 3. Amyloid beta peptide is (synapto)toxic over a wide range of sizes. (a) Lipid-derived amyloid beta peptide (A $\beta$ ) oligomers cause learning and memory impairments in mice. Passive avoidance test of mice injected with backward protofibrils. Light-dark step through test showed latency of entrance during the training accompanied with electrical shock (white bars) and during the testing 24 hours later (black bars). Injection of A $\beta$ fibrils/brain total extract (BTE) mixture-soluble fractions 1.5 hours before the shock impaired memory in contrast to groups injected with control vehicle. From Martins and colleagues [59]. (b). Soluble A $\beta$ extracted from Alzheimer's disease (AD) brain alters hippocampal synapse physiology and learned behaviour. Rats receiving AD Tris-buffered saline (TBS; dashed line) had a significantly shorter mean escape latency than animals receiving immunodepleted AD TBS (continuous line) at 48 hours after training. From Shankar and colleagues [1 1]. (c) Effects of purified brain $A \beta^{*} 56$ (soluble $A \beta$ species with an apparent molecular weight of $56 \mathrm{kDa}$ ) on memory of young rats. $A \beta^{*} 56$ impairs spatial memory. Rats that received vehicle but not $A \beta * 56$ injections showed a significant spatial bias for the escape location 24 hours after training [14]. (d) Vulnerability of NT2 cells to soluble oligomeric A $\beta$ in vitro. The ability of cells to oxidize MTT was used as a measurement of cell viability after treatment with A 3 . Cells were incubated in the presence of different concentrations of either A $\beta$ or equivalent amounts of dimethyl sulfoxide (DMSO) control for 20 hours. The $x$-axis represents the concentration of soluble oligomeric AB. The $y$-axis represents the percentage of viability of cells compared with the DMSO control. From Kim and colleagues [68]. (e) Human cerebrospinal fluid (huCSF) containing clearly detectable A $\beta$ dimers disrupts synaptic plasticity in vivo. Samples of huCSF containing A 3 dimers (hUCSF D) completely inhibited long-term potentiation, and this inhibition was prevented by previous immunodepletion of A $\beta$. Untreated huCSF (open circles), and immunodepleted samples (filled circles) were injected 10 minutes before high-frequency stimulation (arrow). From Klyubin and colleagues [10]. ADDL, A $\beta$-derived diffusible ligand; EPSP, excitatory postsynaptic potential. 
involving the formation of a heterogeneous population of transient toxic $A \beta$ oligomeric species [59]. We found that co-incubation of mature $A \beta$ fibrils with biomimetic membrane particles results in the release of toxic $A \beta$ oligomers, suggesting a fibril to oligomer pathway. Incubation of released $A \beta$ oligomers from fibrils on hippocampal primary neuronal cell cultures resulted in profound cytotoxicity, and animals injected with these oligomers showed significant cognitive decline compared with control animals (Figure 3a). The main question arising from these observations is whether this fibril to oligomer pathway might occur in vivo. Nevertheless, it has been reported that secondary lipid metabolic disorders, such as hypercholesterolemia $[60,61]$ or deregulation of sphingolipid metabolism [62], frequently cooccur with a diagnosis of AD. An interesting link with regard to this is the established fact that the $\varepsilon 4$ allele of the gene encoding apolipoprotein, a cholesterol-carrying protein, has been defined as the major risk factor for AD, while the $\varepsilon 2$ allele is protective $[63,64]$. An extensive review on the role of the apolipoprotein $E$ allele type on progress of $\mathrm{AD}$ has appeared recently [65]. The relevance of such an apolipoprotein $\mathrm{E}$ allele type in the lipid-induced dissociation mechanism leading to sporadic forms of $\mathrm{AD}$ as well as the precise contribution of lipid-induced $A \beta$ fibril dissociation and the link with apolipoprotein $\mathrm{E}$ phenotype in vitro remain to be confirmed.

\section{$A \beta$-derived diffusible ligands}

In 1994 Oda and colleagues $[66,67]$ first mentioned that incorporation of clusterin (apoJ) into an $\mathrm{A} \beta_{1-42}$ solution inhibited mature fibril formation but stabilized a slowly sedimenting $A \beta_{1-42}$ aggregate. Aggregates formed according to this protocol are resistant to low concentrations of SDS (prepared in the presence of clusterin (apoJ)) and enhance oxidative stress in PC12 cells. A similar aggregating species can also be formed in the absence of clusterin by employing cold-induced aggregation [9] These so-called ADDLs potently disrupt long-term potentiation in hippocampal slices from young adult rats at very low concentrations [9], reduce cell viability in a range of different cell lines [68] (Figure 3d) and were found to alter cell viability by affecting membrane thickness and inducing overall ionic leakiness [69]. Structural characterization revealed that ADDLs are small (approximately 4.8 to $5.7 \mathrm{~nm}$ ), soluble globular structures $[9,70]$ with an estimated mass of 17 to $42 \mathrm{kDa}$ (derived using atomic force microscopy (AFM)) [9] that migrate during SDS gel electrophoresis to $17 \mathrm{kDa}$ and $27 \mathrm{kDa}$, with the latter being the predominant species [9]. The very low concentration required for a toxic response led to the hypothesis that ADDL-induced toxicity may be specific and it was postulated that such toxicity might involve specific cell-surface receptors $[9,68]$.

\section{Protofibrils}

Aggregation kinetics of $A \beta_{1-40}$ and $A \beta_{1-42}$ were investigated by Harper and colleagues [18] and Walsh and colleagues [21] using AFM. These studies detected curvilinear, soluble assemblies, termed protofibrillar aggregates, which appeared to be intermediates on the pathway to amyloid fibril formation. Their transient and intermediate nature was confirmed by the finding that these aggregates grow slowly at first and then rapidly disappear in favor of the formation of mature amyloid fibrils [18]. Their involvement in disease was derived from size exclusion chromatography experiments showing that $A \beta_{1-42}$ and $\mathrm{A} \beta_{1-40}$ E22Q (later called the 'Dutch' mutation), accumulate more protofibrils compared with wild-type $A \beta_{1-40}$ [13], and they were found to inhibit memory formation in animals [11] (Figure 3b). Morphological characterization of these protofibrillar structures by AFM, transmission electron microscopy, quasielastic light scattering and size exclusion chromatography revealed that these curvilinear, soluble assemblies have an apparent mass of $>100 \mathrm{kDa}$, a diameter of 6 to $8 \mathrm{~nm}$, and a length of $\leq 200 \mathrm{~nm}[21]$.

\section{Cytotoxicity and neurotoxicity as parameters for development of $A D$ - practical considerations Extraction procedures}

The wide variety of transient and intermediate $A \beta$ species on the pathway to fibril formation (dimers, trimers, higher $n$-mers, protofibrils) that have been detected by several studies over the years have all been found to exert toxicity on cells in a manner that supposedly causes AD (Figure 3). Interestingly, Bernstein and colleagues [71] showed by using ion mobility spectroscopy coupled with nanoelectrospray mass spectrometry that $A \beta_{1-42}$ can spontaneously co-exist as monomeric or as large oligomeric aggregated species. These large species rapidly developed into large aggregates. However, filtration employed to remove large species resulted in the formation of small oligomers that did not convert into large aggregates rapidly.

Various subfibrillar $A \beta$-derived toxins have been detected in vivo [72-74] and these all correlate well with brain dysfunction and degeneration observed in both transgenic mice and humans [7,75]. The extraction and analysis procedures used to study these $A \beta$ fractions involve methods that have been established to dissociate or, at least, destabilize fibrillar proteins and include homogenization, addition of SDS, $\beta$-mercaptoethanol or urea and boiling $[7,75]$. Therefore, it is not clear whether any of these species really occur in the diseased brain.

Another approach, involving the preparation of oligomeric $A \beta$ from a synthetic source and subsequent evaluation of their impact on synaptic activity or cytotoxicity has proven a valuable approach to circumvent 
the use of harsh extraction procedures for analysis of in vivo occurring $\mathrm{A} \beta$. A recent publication by Reed and colleagues [58] compares the effects of $A \beta$ derived from synthetic sources, transfected cells and mouse or human brains. Cognitive effects were studied using the Alternating Lever Cyclic Ratio cognitive assay upon intraventricular injection with $A \beta$ from various sources into rat brains and it was found that $A \beta$ oligomers from all sources are potently able to induce cognitive defects.

\section{The detection of toxic $A \beta$ assemblies by $A 11$ antibody}

The mature fibrillar form and monomeric $A \beta$ have both been confirmed on many occasions as the only non-toxic species. Moreover, co-incubation with the toxic-conformation-recognizing antibody A11 suppresses the toxic effect of $A \beta$ oligomers, suggesting that, even though these $\mathrm{A} \beta$ species vary widely in size and shape, there must be a common denominator to their toxic origin. Even more interestingly, many proteins, either disease-related or nondisease-related, have been found to undergo a specific conformational transition that is toxic to cell cultures and is A11-reactive $[19,76]$. However, A11 reactivity as such does not always correlate well with the potency of $A \beta$ assemblies to induce toxicity, as was reported recently by Noguchi and colleagues [77]. These researchers isolated an A11-negative fraction of $A \beta$ from brains inflicted by $\mathrm{AD}$ or dementia with Lewy Bodies morphologically appearing as a 10 - to $15-\mathrm{nm}$ spherical $A \beta$ species and reproduced these structures using synthetic $A \beta$. Both assemblies induced damage to human neuronal cells and mature rat hippocampal neurons, and these $A \beta$ species were assigned a role in disturbing presynaptic signaling mechanisms [77]. It appears that even though it is potentially useful for preliminary screening for toxic potency, A11-negativity does not exclude the possibility of $A \beta$ assemblies playing a major role in the disease mechanism of $\mathrm{AD}$. It is hence advisable to combine studies using the A11 antibody with complementary results on the neurotoxicity of detected or isolated $A \beta$ species.

\section{The complex cellular environment}

An important discussion that tightly links into the field of defining the most toxic species of $A \beta$ is that on defining to what extent cytotoxic and neurotoxic results actually represent in vivo pathophysiological mechanisms leading to $\mathrm{AD}$. A wide range of results are used to assay for the effects of $A \beta$ on (neuronal) cells, which can be divided into experiments probing for general cytotoxic, and more specific neurotoxic deviations. For example, assays that exclusively evaluate the cytotoxic effects of $A \beta$ species largely ignore subtle changes that have been shown to occur in the metabolism and functional output of neuronal cells prior to overt cell death (reviewed in [78]).
$\mathrm{A} \beta$ is known to be a dynamic molecule, converting from monomeric through a number of lesser-defined oligomeric stages to mature plaques; as a consequence, time points at which cytotoxicity is observed do not reflect the initial stages of the damage $\mathrm{A} \beta$ inflicts.

A further complication with regard to neurotoxic results is that the actual initial stages of the disease are not known and have been reported to involve, for example, microglia cells of other than neuronal origin (reviewed in [79]). An elaborative review on the toxic effects of $\mathrm{Cu} / \mathrm{Zn}$ superoxide dismutase (SOD1), implicated in amyotrophic lateral sclerosis, illustrates how the protein can affect multiple cell types in a highly complex manner which, judging from the complexity of the brain anatomy as well as the difficulty in developing a treatment and pinpointing the actual triggers for onset of $\mathrm{AD}$, may well be applicable to AD as well [80].

These findings suggest that one single result does not necessarily embrace all the facets involved in the development of $\mathrm{AD}$ and underlines the necessity to employ a multidisciplinary approach, including assays to report on the early effects (for example, long-term depression (LDP) or synaptic activity read-outs) and late effects (cytotoxic effects) of $\mathrm{A} \beta$ on a cellular level as well as, for example, cognition assays to evaluate the progress of the condition overall. It further implies the importance of investigating the continuity of the disease in terms of time lines of appearance of specific symptoms and cellular effects rather than a single time point or $A \beta$ species. A publication that illustrates the dynamic effects of $A \beta$ toxicity rather well shows that $A \beta$-mediated neuronal cell death is a dynamic process, depending on the progress of the aggregation pathway of $A \beta$, rather than a stable situation [81].

\section{Analyses for AD-linked pathophysiology: the MTT assay}

It is worth mentioning some issues with regard to the actual measurement of the potency of $A \beta$ species to induce potentially pathophysiological effects in $\mathrm{AD}$ models. A frequently used assay for this purpose is the MTT assay, which is based on the conversion of yellow 3-(4,5-dimethylthiazol-2-yl)-2,5-diphenyltetrazolium bromide (a tetrazole) into purple insoluble formazan. The formazan compound is subsequently solubilized by a solubilization solution and the absorbance of soluble formazan can be measured spectrophotometrically [82]. The reduction reaction to formazan can, however, be affected by $\mathrm{A} \beta$ in the absence of cell death [83-85]. A number of potential reasons for this effect have been discussed by Wogulis and colleagues [81] and range from variations in formazan crystal morphology, exocytosis of MTT formazan, MTT-induced interaction of A $\beta$ with intracellular targets and effects of $A \beta$ on the neuronal membrane. 


\section{The concentration debate}

A further discrepancy that is frequently highlighted in the literature is the observation that often non-physiologically related and excessive concentrations of in vitro prepared $A \beta$ are required to observe detrimental effects. For example, in cell cultures $A \beta$ usually needs to be added in the micromolar range for effects to be observed, while physiological concentrations of $\mathrm{A} \beta$ in vivo are estimated to be in the nanomolar range. One recent publication provides a potential answer to this question by showing that $A \beta$ can be taken up by neuronal-like cells but not neuron-unrelated kidney cells. Upon uptake, A $\beta$ can accumulate in late endosomes or lysosomes, where $A \beta$ concentrations of up to $2.5 \mu \mathrm{M}$ can be reached. At such elevated concentrations $A \beta$ was found to form high molecular weight $\mathrm{A} \beta$ assemblies and these assemblies can, in turn, seed amyloid fibril formation [86].

\section{Toxic species or building block?}

It is entirely possible that all the preparations mentioned in the previous paragraphs are unified by a highly potent neurotoxic $A \beta$ assembly of well defined size that is present at concentrations that preclude direct detection but mediate toxicity effectively, and that this elusive species is the cause of AD. However, it is more likely that a wide range of $A \beta$ oligomers are toxic. Given that the reaction mixture is highly heterogeneous, the purified species is an almost arbitrary result of the conditions chosen to enrich the fraction and the method employed to establish a size estimate. The apparent molecular weight of a particular fraction is usually estimated from its elution profile from matrix-assisted molecular sieving techniques, such as gel electrophoresis and size exclusion chromatography, often carried out in the presence of low concentrations of SDS $(0.1 \%)$. In order to arrive at a molecular weight estimate, the mobility of the oligomeric fraction needs to be compared to those of other proteins and peptides that act as molecular weight standards. There are several problems with this approach. First, in the absence of even these low doses of detergent, the elution profiles show almost exclusively higher molecular weight assemblies, raising the question of whether the reported molecular size corresponds to the neurotoxin itself or merely to a stable fragment $[22,23,87]$. Second, comparison with migration profiles of reference proteins is not reliable for aggregating proteins that have a notorious feature that is systematically underestimated in the AD field: amyloid fibrils and their precursors are employed in nature for their mechanical strength and high adhesiveness on a range of surfaces. Bacteria, for example, employ curli amyloids for adhesion to host organism tissues or to colonize a synthetic surface [88]. When such preparations are subjected to molecular sieving, they will hence be sorted by their affinity for the matrix and resistance to the employed flow rate, thereby obliterating the main assumption required to use molecular sieving profiles to estimate size. When sample fractionation is achieved in detergent free buffers, and the molecular weight is measured using an absolute technique, such as static light scattering, that does not require comparison of the migration rate through some chemical matrix, significantly higher molecular weight species have been observed, both by us [59] and by others [89].

In conclusion, it remains unclear which of the species discussed above occurs as quasi-independent units in the brain of $\mathrm{AD}$ patients or if they are usually part of larger molecular assemblies. After all, the extraction procedures used may importantly affect the $A \beta$ species obtained, which might not necessarily reflect those involved in the development of AD. One apparent conclusion that can be drawn is that the toxic form is neither monomeric nor fibrillar, and that the toxic species is a soluble form of $A \beta$. As oligomer size does not correlate tightly with the progression of $\mathrm{AD}$, it seems likely that the toxic behavior can be induced by factors other than oligomer size alone.

\section{The structural requirements of a neurotoxin}

A complete overview of the pathways through which $A \beta$ oligomers are thought to mediate toxicity falls well outside the scope of this article and these are reviewed extensively elsewhere $[90,91]$. However, we need to briefly consider them here in order to understand the structural requirements for toxicity-mediating interactions. It now seems that soluble $A \beta$ oligomers do not affect the lifecycle of neurons in general but that the effect may be more specifically related to the interference of synaptic function, judging from the low effective dosage required to induce a toxic response [9], and more specifically, that $A \beta$ oligomers interfere with the machinery responsible for synaptic vesicle release at the presynaptic terminal (for reviews see $[53,92]$ ).

Two major classes of mechanisms have been proposed to explain how $\mathrm{A} \beta$ oligomers interact toxically with the cell. One class is receptor-mediated interactions, such as the previously proposed interactions between receptor $\mathrm{X}$ and ADDLs [40], the interaction with $N$-methyl $D$ aspartate receptors $[93,94]$ or the interaction with human prion proteins by the Strittmatter group [95]. Although the conformational requirements for receptor-mediated toxicity have not been extensively studied, we know from other protein-peptide interactions that structural requirements are usually very specific [96]. The second major group of toxic mechanisms involve some form of membrane disruption, which is also a much explored potential disease mechanism for several other amyloidoses (for a review see [97]), lending support to the idea that amyloid formation by any peptide sequence goes through a toxic intermediate structure. In fact, a common 
mechanism for amyloid toxicity, such as was proposed by Dobson and Stefani and colleagues [98] from toxicity studies of a range of amyloid fibrils, could be equally compatible with a receptor-mediated interaction, although the focus in this field has been strongly on membrane disruption. Another strong line of support for the notion of a toxic conformation comes from the conformationspecific antibody A11, which also recognizes several other amyloidogenic proteins and peptides that are known to form pore-compatible oligomers $[19,99]$. A recent review by Glabe [100] explores the concept of conformationdependent toxicity in more detail.

The strong focus on the sizes of $A \beta$ assemblies that display potency in the disruption of neuronal function may falsely give the impression that other structural aspects, like peptide conformation, are being neglected. However, when considering the possible molecular mechanisms by which the $A \beta$ peptide exerts its toxicity, the conformation of the individual peptide in the molecular assembly is clearly a critical factor that needs to be carefully considered, and both receptor-mediated interaction and membrane disruption models impose specific structural requirements on the oligomers. Progress in this field is slow, however, since techniques for studying peptide conformations suffer from the experimental difficulties of working with heterogeneous aggregating samples even more than molecular sizing techniques as they generally require higher peptide concentrations, further promoting aggregation.

The seemingly conflicting results obtained by different groups on the size requirements of the toxic $A \beta$ oligomer could be elegantly unified when a model is considered in which peptide oligomerization provides the necessary intermolecular interactions required to stabilize a toxic conformation that cannot be adopted by a monomer in isolation. In such a model any oligomer could be toxic as long as its constituent peptides are maintained by the intermolecular interactions in the appropriate conformation to mediate toxicity, rendering dimers as potently toxic as 12-mers or higher order oligomers. The model would further predict that oligomerization is required per se (independent of exact size) and that a specific conformation needs to accumulate in the $A \beta$ oligomer fraction in correspondence with toxicity.

\section{Structural studies detect a specific conformation of toxic oligomers}

Substantial evidence supports the hypothesis that fibrillar $A \beta$ is conformationally distinct from monomeric $A \beta$ but the investigation into the specific structural transition states of $A \beta$ along the pathway to mature fibrils has been hampered by the inability to arrest the transient $A \beta$ oligomers in stable, intermediate conformations. A variety of spectroscopic techniques have shown that monomeric
$A \beta$ is disordered in aqueous solution, adopting some nonrandom, local conformations [101,102]; thus, it can be categorized as a 'natively disordered' protein, such as $\alpha$-synuclein, which is implicated in Parkinson's disease (for a review on natively disordered proteins see [103]). Solid-state NMR studies have revealed that $A \beta$ fibrils are organized in a parallel $\beta$-sheet structure (for a review see [104]). Site-directed spin labeling showed that fibrillar core regions are composed of 20 amino acids or more (for a review see [105]) and the cores of most amyloid fibrils, including those composed of $A \beta$, have been found to assume a typical steric zipper conformation [106].

The question that arises is: does unstructured $A \beta$ directly transform into a well-organized fibril or is/are an intermediate(s) involved? Moreover, how does such a transition in structure relate to the toxicity observed for oligomeric $A \beta$ ? A structural investigation using circular dichroism on the fibrillation pathway of $A \beta_{1-40}$ by Walsh and colleagues [107] suggests that $A \beta$ first forms a transitory $\alpha$-helical conformation and then transforms into a $\beta$-sheet characteristic for fibrillar $A \beta$. Accumulation of early $\alpha$-helical enriched intermediates has been reported before using in vitro experiments and molecular modeling [43,107-110]. Whether $\alpha$-helix formation is relevant within the AD context or is on- [108] or offpathway [111] has been an issue of debate. However, the fact that aggregation and toxic effects in cell culture and hippocampal slices are inhibited and that locomotor activity is improved and the lifespan prolonged in Drosophila melanogaster in the presence of ligands that bind to and stabilize a region in $A \beta$ in an $\alpha$-helical conformation [110] supports the on-pathway paradigm. Such an effect can be explained either by a neutralizing effect on toxic $\alpha$-helical $A \beta$ or, alternatively, by these inhibitors blocking earlier stages in the aggregation process that can lead to the formation of the actual toxic species. The occurrence of a kinetic intermediate composed of $\alpha$-helical components is not limited to $A \beta$ but is also observed for a range of other peptides, such as insulin [112,113] and a model 38-residue helix-turn-helix peptide, $\alpha$ t $\alpha$ [114].

Computational analysis of the fibrillation pathways of $A \beta_{1-40}$ and familial $A D$-related mutations suggests that early events involve the formation of an ordered, cross- $\beta$ structured nucleus composed of six to ten monomer chains [115]. This supports an earlier proposition by Grant and colleagues [116] that the aggregate seed for $A \beta$ involves a specific type of collapsed structure involving exposed $\beta$-strands. The evolution of $\beta$-structure upon higher order oligomerization and fibrillation has been published many times using a range of spectroscopic techniques, including circular dichroism $[31,107,108]$, fiber X-ray crystallography [106] and Fourier transform infrared spectroscopy [32,43], and also by computational methods [109]. If both mature fibrils and growing 
oligomers exhibit $\beta$-sheet structure, then what determines their differential toxic effects? Work by the group of Goormaghtigh has shown, using attenuated total reflection Fourier transform infrared spectroscopy, that an anti-parallel $\beta$-sheet conformation of $A \beta$ distinguishes the oligomeric structure from the parallel $\beta$-sheet structure of mature fibrils [43]. The experimental set-up used ensured careful preparation conditions for $A \beta$ to obtain solutions enriched in either oligomeric or fibrillar $A \beta$. To support this suggestion, the work by $Y u$ and colleagues [44] used NMR to show that oligomeric intermediate assemblies stabilized by the addition of detergents and fatty acids have a mixed parallel and antiparallel $\beta$-sheet structure that can alter synaptic activity. On a longer timescale this anti-parallel $\beta$-sheet rearranges into a less flexible parallel $\beta$-sheet characteristic for fibrillar $A \beta$ [43]. If the membrane-peptide interactions are indeed responsible for the onset of the cascade of toxic responses leading to cell death, then mutations in $A \beta$ leading to early onset cases of AD should show considerably more pronounced interaction with membranes.

\section{Conformational antibodies, $\beta$-sheet breaker compounds and mutation are effective disruptors of $A \beta$ toxicity}

The introduction of $\beta$-sheet breaking amino acids in the carboxyl terminus of $A \beta_{1-42}$ [117-119], or co-incubation with $\beta$-sheet breaking compounds [120-123] or peptides [124] have been shown to be highly effective inhibitors of $A \beta$ aggregation and to reduce toxic responses to $A \beta$ in a neuronal cell culture $[117,119]$. The relevance of $\beta$-sheet structure for toxicity has also been supported by the finding that many proteins respond to the conformationspecific antibody A11 [19], including natively folded proteins not related to disease - for example, a GroEL oligomer complex, a bacterial chaperonin [76], heat shock proteins $27,40,70$, and 90 , yeast heat shock protein 104 and bovine heat shock cognate 70 [76], but also transthyretin and $\alpha 2$-macroglobulin, both proteins associated with aggregation themselves and found to have a $\beta$-sandwich topology [125-128]. Interestingly and analogous to $\beta$-sheet breaker peptides, co-incubation of $A \beta$ and a range of other oligomeric aggregates from $\alpha$ synuclein, islet amyloid polypeptide, polyglutamine, lysozyme, human insulin, and prion peptide 106-126 with other A11-positive proteins has an anti-aggregation effect on $A \beta[19]$ similar to co-incubation with A11 antibody [76] and limits toxicity in neuroblastoma SH-SY5Y cells as assessed by the 3-[4,5dimethylthiazol-2-yl]-2,5diphenyltetrazolium bromide reduction assay and lactate dehydrogenase release [19]. Moreover, recent work by Yoshiike and colleagues [76] has defined the epitope of the A11 antibody as the $\beta$-sheet edge of proteins. The A11 antibody is reactive to the $A \beta$ oligomer conformation over a wide timeframe and recognizes pentameric $A \beta$ up to protofibrils [19]. This finding strongly suggests a structural similarity between all these species, which could be related to toxicity.

SDS-stable tetramers and dimers are not recognized by the A11 antibody [19] but still have been found to exert profound toxicity in cell culture $[11,56]$. However, extraction procedures to obtain dimeric and other low- $n$ aggregated $A \beta$ from tissue and neuronal cells that involve SDS or sonication could partly dissociate small oligomers into their basic building blocks. These findings show that toxic oligomeric $A \beta$, over a wide range of sizes, has a structure distinct from monomeric or fibrillar $A \beta$, which might provide the key to their toxic potential.

\section{Conclusion}

The studies reviewed above highlight the challenging nature of identifying the critical component of the complex and constantly evolving reaction mixture that is the ageing $A \beta$ peptide solution. However, the potential result will be highly rewarding as it will allow us to understand how known risk factors for AD map onto the formation of toxic intermediates of amyloid formation: do well established risk factors such as carboxy-terminal heterogeneity, the apolipoprotein $\mathrm{E}$ allele and age act by stabilizing the toxic substructures, and if so, which therapeutic interventions are best suited for counteracting these effects? Moreover, as long as we cannot accurately model the accumulation of the neurotoxic species, we cannot be certain that therapeutic intervention will produce the desired outcome. For example, an overall decrease in the concentration of $A \beta$ may stabilize low- $n$ oligomers, thereby potentially increasing rather than decreasing toxicity.

In conclusion, a wide range of $\mathrm{AD}$-related (synapto) toxic $A \beta$ oligomeric sizes have been identified. How oligomer size precisely relates to the disease process has not been clarified and recent work shows that the wide range of $A \beta$ oligomers may have a specific conformation in common. These findings suggest that $A \beta$ oligomer size may not be the only AD-inducing factor and we propose a new paradigm in which both oligomer size and structural arrangement act as toxic parameters in AD development. Studies targeting the toxic contributor to AD in the past have usually highlighted only one of these aspects, but we suggest that further studies should employ a multidisciplinary approach in which oligomer size, structural characteristics and synaptic activity results are recorded simultaneously over a long kinetic timeframe. Sufficient resolution in such a kinetic study should allow access to structural information on transient intermediates, which may be further supported by employing means of stabilizing these species using cross-linking, conformation-sensitive antibodies or lipid-induced fibril dissociation and by studying familial AD-related mutations in $\mathrm{A} \beta$. 


\section{Abbreviations}

$A B=$ amyloid beta peptide; $A D=$ Alzheimer's disease; $A D D L=A \beta$-derived diffusible ligand; AFM = atomic force microscopy; CSF = cerebrospinal fluid; NMR = nuclear magnetic resonance; SDS = sodium dodecyl sulfate.

\section{Competing interests}

The authors declare that they have no competing interests.

\section{Acknowledgements}

We acknowledge the following people for valuable discussions and/or critical reading of the manuscript: Bart De Strooper, Iryna Benilova, Patrick Van Gelder, Kris Pauwels, Giulietta Spudich, Jose Couceiro, Jean-Marie Ruysschaert, Emilie Cerf, and Vincent Raussens. We acknowledge Joost Van Durme for his technical support providing the molecular dynamics and Yasara images. Research into Alzheimer's disease at the Switch laboratory is funded by an FWO Odysseus grant, and the Alzheimer Research Trust (ART) UK.

\section{Published: 14 July 2010}

\section{References}

1. Hardy JA, Higgins GA: Alzheimer's disease: the amyloid cascade hypothesis. Science 1992, 256:184-185.

2. Hardy J, Selkoe DJ: The amyloid hypothesis of Alzheimer's disease: progress and problems on the road to therapeutics. Science 2002, 297:353-356.

3. Haass, C, Schlossmacher MG, Hung AY, Vigo-Pelfrey C, Mellon A, Ostaszewski BL, Lieberburg I, Koo EH, Schenk D, Teplow DB, Selkoe DJ: Amyloid betapeptide is produced by cultured cells during normal metabolism. Nature 1992, 359:322-325.

4. Pike CJ, Walencewicz AJ, Glabe CG, Cotman CW: In vitro aging of betaamyloid protein causes peptide aggregation and neurotoxicity. Brain Res 1991, 563:311-314.

5. Dickson DW, Crystal HA, Bevona C, Honer W, Vincent I, Davies P: Correlations of synaptic and pathological markers with cognition of the elderly. Neurobiol Aging 1995, 16:285-298.

6. Korczyn AD: The amyloid cascade hypothesis. Alzheim Dementia 2008 4:176-178.

7. McLean CA, Cherny RA, Fraser FW, Fuller SJ, Smith MJ, Beyreuther K, Bush Al, Masters DL: Soluble pool of Abeta amyloid as a determinant of severity of neurodegeneration in Alzheimer's disease. Ann Neurol 1999, 46:860-866.

8. Lacor PN, Buniel MC, Chang L, Fernandez SJ, Gong Y, Viola KL, Lambert MP Velasco PT, Bigio EH, Finch CE, Krafft GA, Klein WL: Synaptic targeting by Alzheimer's-related amyloid beta oligomers. J Neurosci 2004, 24:10191-10200.

9. Lambert MP, Barlow AK, Chromy BA, Edwards C, Freed R, Liosatos M, Morgan TE, Rozovsky I, Trommer B, Viola KL, Wals P, Zhang C, Finch CE, Krafft GA, Klein $W L$ : Diffusible, nonfibrillar ligands derived from $A \beta_{1-42}$ are potent central nervous system neurotoxins. Proc Natl Acad Sci U S A 1998, 95:6448-6453.

10. Klyubin I, Betts V, Welzel AT, Blennow K, Zetterberg H, Wallin A, Lemere CA Cullen WK, Peng Y, Wisniewski T, Selkoe DJ, Anwyl R, Walsh DM, Rowan MJ: Amyloid beta protein dimer-containing human CSF disrupts synaptic plasticity: prevention by systemic passive immunization. J Neurosci 2008, 28:4231-4237

11. Shankar GM, Li S, Mehta TH, Garcia-Munoz A, Shepardson NE, Smith I, Brett FM, Farrell MA, Rowan MJ, Lemere CA, Regan CM, Walsh DM, Sabatini BL, Selkoe DJ: Amyloid- $\beta$ protein dimers isolated directly from Alzheimer's brains impair synaptic plasticity and memory. Nat Med 2008, 14:837-842.

12. Shankar GM, Leissring MA, Adame A, Sun X, Spooner E, Masliah EJ, Selkoe DJ, Lemere CA, Walsh DM: Biochemical and Immunohistochemical analysis of an Alzheimer's disease mouse model reveals the presence of multiple cerebral A $\beta$ assembly forms throughout life. Neurobiol Dis 2009, 36:293-302.

13. Townsend M, Shankar G, Mehta T, Walsh D, Selkoe D: Effects of secreted oligomers of amyloid beta-protein on hippocampal synaptic plasticity: a potent role for trimers. J Physio/ 2006, 572:477-492.

14. Lesné S, Koh MT, Kotilinek L, Kayed R, Glabe CG, Yang A, Gallagher M, Ashe $\mathrm{KH}$ : A specific amyloid-beta protein assembly in the brain impairs memory. Nature 2006, 440:352-357.

15. Gong Y, Chang L, Viola KL, Lacor PN, Lambert MP, Finch CE, Krafft GA, Klein WL: Alzheimer's disease-affected brain: presence of oligomeric $A$ beta ligands (ADDLs) suggests a molecular basis for reversible memory loss. Proc Natl Acad Sci U S A 2003, 100:10417-10422.

16. Viola KL, Velasco PT, Klein WL: Why Alzheimer's is a disease of memory: the attack on synapses by A beta oligomers (ADDLs). J Nutr Health Aging 2008, 12:51S-57S.

17. Kayed R, Pensalfini A, Margol L, Sokolov Y, Sarsoza F, Head E, Hall J, Glabe C: Annular protofibrils are a structurally and functionally distinct type of amyloid oligomer. J Biol Chem 2009, 284:4230-4237.

18. Harper JD, Wong SS, Lieber CM, Lansbury PT: Observation of metastable A $\beta$ amyloid protofibrils by atomic force microscopy. Chem Biol 1997, 4:119-125.

19. Kayed R, Head E, Thompson JL, McIntire TM, Milton SC, Cotman CW, Glabe CG: Common structure of soluble amyloid oligomers implies common mechanism of pathogenesis. Science 2003, 300:486-489.

20. Lashuel HA, Petre BM, Wall J, Simon M, Nowak RJ, Walz T, Lansbury PT: Alphasynuclein, especially the Parkinson's disease-associated mutants, forms pore-like annular and tubular protofibrils. J Mol Biol 2002, 322:1089-1102.

21. Walsh DM, Lomakin A, Benedek GB, Condron MM, Teplow DB: Amyloid $\beta$ protein fibrillogenesis. Detection of a protofibrillar intermediate. J Biol Chem 1997, 272:22364-22372.

22. Lanz TA, Schachter JB: Demonstration of a common artifact in immunosorbent assays of brain extracts: development of a solid-phase extraction protocol to enable measurement of amyloid-beta from wildtype rodent brain. J Neurosci Methods 2006, 157:71-81

23. Yu W, Zou K, Gong JS, Ko M, Yanagisawa K, Michikawa M: Oligomerization of amyloid beta-protein occurs during the isolation of lipid rafts. J Neurosci Res 2005, 80:114-119.

24. Jan A, Gokce O, Luthi-Carter R, Lashuel HA: The ratio of monomeric to aggregated forms of Abeta40 and Abeta42 is an important determinant of amyloid-beta aggregation, fibrillogenesis, and toxicity. J Biol Chem 2008, 283:28176-28189.

25. Bitan G, Kirkitadze MD, Lomakin A, Vollers SS, Benedek GB, Teplow DB: Amyloid beta protein (Abeta) assembly: Abeta40 and Abeta42 oligomerize through distinct pathways. Proc Natl Acad Sci U S A 2003, 100:330-335.

26. Finder VH, Glockshuber R: Amyloid-beta aggregation. Neurodegen Dis 2007, 4:13-27.

27. Rahimi F, Shanmugam A, Bitan G: Structure-function relationships of prefibrillar protein assemblies in Alzheimer's disease and related disorders. Curr Alzh Res 2008, 5:319-341.

28. Walsh DM, Selkoe DJ: Oligomers on the brain: the emerging role of soluble protein aggregates in neurodegeneration. Protein Pept Lett 2004, 11:213-228.

29. Harper JD, Lansbury PT Jr: Models of amyloid seeding in Alzheimer's disease and scrapie: mechanistic truths and physiological consequences of the time-dependent solubility of amyloid proteins. Annu Rev Biochem 1997, 66:385-407.

30. Taylor BM, Sarver RW, Fici G, Poorman RA, Lutzke BS, Molinari A, Kawabe T, Kappenman K, Buhl AE, Epps DE: Spontaneous aggregation and cytotoxicity of the $\beta$-amyloid $A \beta^{1-40}$ : a kinetic model. J Prot Chem 2003, 22:31-40.

31. Bartolini M, Bertucci C, Bolognesi ML, Cavalli A, Melchiorre C, Andrisano V: Insights into the kinetic of amyloid $\beta$ (1-42) peptide self-aggregation: elucidation of inhibitor's mechanism of action. ChemBioChem 2007, 8:2152-2161.

32. Benseny-Cases N, Cócera M, Cladera J: Conversion of non-fibrillar $\beta$-sheet oligomers into amyloid fibrils in Alzheimer's disease amyloid peptide aggregation. Biochem Biophys Res Commun 2007, 361:916-921.

33. Abedini A, Raleigh DP: A critical assessment of the role of helical intermediates in amyloid formation by natively unfolded proteins and polypeptides. Prot Eng Des Sel 2009, 22:453-459.

34. Daidone I, Simona F, Roccatano D, Broglia RA, Tiana G, Colombo G, Nola AD: Beta-hairpin conformation of fibrillogenic peptides: structure and alphabeta transition mechanism revealed by molecular dynamics simulations. Proteins 2004, 57:198-204.

35. Kallberg Y, Gustafsson M, Persson B, Thyberg J, Johansson J: Prediction of amyloid fibril-forming proteins. J Bio/ Chem 2001, 276:12945-12950.

36. Williamson MP, Suzuki Y, Bourne NT, Asakura T: Binding of amyloid betapeptide to ganglioside micelles is dependent on histidine-13. Biochem J 2006, 397:483-490

37. Xu Y, Shen J, Luo X, Zhu W, Chen K, Ma J, Jiang H: Conformational transition of amyloid beta-peptide. Proc Natl Acad Sci U S A 2005, 102:5403-5407.

38. Privé GG: Lipopeptide detergents for membrane protein solvents. Curr Opin Struct Biol 2009, 19:379-386.

39. Hou L, Shao H, Zhang Y, Li H, Menon NK, Neuhaus EB, Brewer JM, Byeon, I-JL, 
Ray DG, Vitek MP, Iwashita T, Makula RA, Przybyla AB, Zagorski MG: Solution NMR studies of the $A \beta(1-40)$ and $A \beta(1-42)$ peptides establish that the Met35 oxidation state affects the mechanism of amyloid formation. J Am Chem Soc 2004, 126:1992-2005.

40. Sgourakis NG, Yan Y, McCallum SA, Wang C, Garcia AE: The Alzheimer's peptides $\mathrm{Ab} 40$ and 42 adopt distinct conformations in water: a combined MD/NMR study. J Mol Biol 2007, 368:1448-1457.

41. Canet D, Sunde M, Last AM, Miranker A, Spencer A, Robinson CV, Dobson CM: Mechanistic studies of the folding of human lysozyme and the origin of amyloidogenic behavior in its disease-related variants. Biochemistry 1999, 38:6419-6427.

42. Marcon G, Plakoutsi G, Canale C, Relini A, Taddei N, Dobson CM, Ramponi G, Chiti F: Amyloid formation from HypF-N under conditions in which the protein is initially in its native state. J Mol Biol 2005, 347:323-335.

43. Cerf E, Sarroukh R, Tamamizu-Kato S, Breydo L, Derclaye S, Dufrêne Y, Narayanaswami V, Goormaghtigh E, Ruysschaert JM, Raussens V: Anti-parallel beta-sheet - a signature structure of the oligomeric amyloid-beta peptide. Biochem J 2009, 421:415-423.

44. Yu L, Edalji R, Harlan JE, Holzman TF, Pereda Lopez A, Labkovsky B, Hillen H, Barghorn S, Ebert U, Richardson PL, Miesbauer L, Solomon L, Bartley D, Walter K, Johnson RW, Hajduk PJ, Olejniczak ET: Structural characterization of a soluble amyloid $\beta$-peptide oligomer. Biochemistry 2009, 48:1870-1877.

45. Lührs T, Ritter C, Adrian M, Riek-Loher D, Bohrmann B, Dobeli H, Schubert D, Riek R: 3D structure of Alzheimer's amyloid-beta (1-42) fibrils. Proc Natl Acad SciU S A 2005, 102:17342-17347.

46. Török M, Milton S, Kayed R, Wu P, McIntire T, Glabe CG, Langen R: Structural and dynamic features of alzheimer's $A \beta$ peptide in amyloid fibrils studied by site-directed spin labeling. J Biol Chem 2002, 277:40810-40815.

47. Cleary JP, Walsh DM, Hofmeister JJ, Shankar GM, Kuskowski MA, Selkoe DJ, Ashe KH: Natural oligomers of the amyloid-beta protein specifically disrupt cognitive function. Nat Neurosci 2005, 8:79-84.

48. Walsh DM, Klyubin I, Fadeeva JV, Cullen WK, Anwyl R, Wolfe MS, Rowan MJ, Selkoe DJ: Naturally secreted oligomers of amyloid beta protein potently inhibit hippocampal long-term potentiation in vivo. Nature 2002, 416:535-539.

49. Hartley DM, Walsh DM, Ye CP, Diehl T, Vasquez S, Vassilev PM, Teplow DB, Selkoe DJ: Protofibrillar intermediates of amyloid beta-protein induce acute electrophysiological changes and progressive neurotoxicity in cortical neurons. J Neurosci 1999, 19:8876-8884.

50. Klyubin I, Walsh DM, Cullen WK, Fadeeva JV, Anwyl R, Selkoe DJ, Rowan MJ: Soluble Arctic amyloid beta protein inhibits hippocampal long-term potentiation in vivo. Eur J Neurosci 2004, 19:2839-2846.

51. Lacor PN, Buniel MC, Furlow PW, Clemente AS, Velasco PT, Wood M, Viola KL, Klein WL: Abeta oligomer-induced aberrations in synapse composition, shape, and density provide a molecular basis for loss of connectivity in Alzheimer's disease. J Neurosci 2007, 27:796-807.

52. Wang Q, Walsh DM, Rowan MJ, Selkoe DJ, Anwyl R: Block of long-term potentiation by naturally secreted and synthetic amyloid beta-peptide in hippocampal slices is mediated via activation of the kinases c-Jun $\mathrm{N}$-terminal kinase, cyclin-dependent kinase 5, and p38 mitogen-activated protein kinase as well as metabotropic glutamate receptor type 5 . J Neurosci 2004, 24:3370-3378.

53. Nimmrich V Ebert U: Is Alzheimer's disease a result of presynaptic failure? Synaptic dysfunctions induced by oligomeric beta-amyloid. Rev Neurosci 2009, 20:1-12.

54. Yoshiike Y, Akagi T, Takashima A: Surface structure of amyloid-b fibrils contributes to cytotoxicity. Biochemistry 2007, 46:9805-9812.

55. Puzzo D, Arancio O: Fibrillar beta-amyloid impairs the late phase of long term potentiation. Curr Alzheimer Res 2006, 3:179-183.

56. Roher AE, Chaney MO, Kuo YM, Webster SD, Stine WB, Haverkamp L, Woods AS, Cotter RJ, Tuohy RJ, Krafft GA, Bonnell BS, Emmerling MR: Morphology and toxicity of Abeta-(1-42) dimer derived from neuritic and vascular amyloid deposits of Alzheimer's disease. J Biol Chem 1996, 271:20631-20635.

57. Xia W, Yang T, Shankar G, Smith IM, Shen Y, Walsh DM, Selkoe DJ: A specific enzyme-linked immunosorbent assay for measuring beta-amyloid protein oligomers in human plasma and brain tissue of patients with Alzheimer disease. Arch Neurol 2009, 66:190-199.

58. Reed MN, Hofmeister JJ, Jungbauer L, Welzel AT, Yu C, Sherman MA, Lesné S, LaDu MJ, Walsh DM, Ashe KH, Cleary JP: Cognitive effects of cell-derived and synthetically derived A $\beta$ oligomers. Neurobiol Aging 2009 [Epub ahead of print].
59. Martins IC, Kuperstein I, Wilkinson H, Maes E, Vanbrabant M, Jonckheere W, Van Gelder P, Hartmann D, D'Hooge R, De Strooper B, Schymkowitz J, Rousseau F: Lipids revert inert Abeta amyloid fibrils to neurotoxic protofibrils that affect learning in mice. EMBO J 2008, 27:224-233.

60. Anstey KJ, Lipnicki DM, Low LF: Cholesterol as a risk factor for dementia and cognitive decline: a systematic review of prospective studies with metaanalysis. Am J Geriatr Psychiatry 2008, 16:343-354.

61. Xiong H, Callaghan D, Jones A, Walker DG, Lue LF, Beach TG, Sue LI, Woulfe J, Xu H, Stanimirovic DB, Zhang W: Cholesterol retention in Alzheimer's brain is responsible for high beta- and gamma-secretase activities and Abeta production. Neurobiol Dis 2008, 29:422-437.

62. He X, Huang Y, Li B, Gong CX, Schuchman EH: Deregulation of sphingolipids metabolism in Alzheimer's disease. Neurobiol Aging 2010, 31:398-408.

63. Corder EH, Saunders AM, Strittmatter WJ, Schmechel DE, Gaskell PC, Small GW, Roses AD, Haines JL, Pericak-Vance MA: Gene dose of apolipoprotein E type 4 allele and the risk of Alzheimer's disease in late onset families. Science 1993, 261:921-923.

64. Strittmatter WJ, Saunders AM, Schmechel D, Pericak-Vance M, Enghild J, Salvesen GS, Roses AD: Apolipoprotein E: high-avidity binding to betaamyloid and increased frequency of type 4 allele in late-onset familial Alzheimer disease. Proc Natl Acad SciU S A 1993, 90:1977-1981.

65. Kim J, Basak JM, Holtzman DM: The role of apolipoprotein E in Alzheimer's disease. Neuron 2009, 63:287-303.

66. Oda T, Pasinetti GM, Osterburg HH, Anderson C, Johnson SA, Finch CE: Purification and characterization of brain clusterin. Biochem Biophys Res Commun 1994, 204:1131-1136.

67. Oda T, Wals P, Osterburg HH, Johnson SA, Pasinetti GM, Morgan TE, Rozovsky I, Blaine Styne W, Snyder SW, Holzman TF, Krafft GA, Finch CE: Clusterin (apoJ) alters the aggregation of amyloid $\beta$-peptide $\left(A \beta_{1-42}\right)$ and forms slowly sedimenting $A \beta$ complexes that cause oxidative stress. Exp Neurol 1995, 136:22-31.

68. Kim HJ, Chae SC, Lee DK, Chromy B, Lee SC, Park YC, Klein WL, Krafft GA, Hong ST: Selective neuronal degeneration induced by soluble oligomeric amyloid beta protein. FASEB J 2003, 17:118-120.

69. Sokolov Y, Kozak JA, Kayed R, Chanturia A, Glabe CG, Hall JE: Soluble amyloid oligomers increase bilayer conductance by altering dielectric structure. J Gen Physiol 2006, 128:637-647.

70. Chromy BA, Nowak RJ, Lambert MP, Viola KL, Chang L, Velasco PT, Jones BW, Fernandez SJ, Lacor PN, Horowitz P, Finch CE, Krafft GA, Klein WL: Selfassembly of $A B(1-42)$ into globular neurotoxins. Biochemistry 2003, 42:12749-12760

71. Bernstein SL, Wyttenbach T, Baumketner A, Shea J-E, Bitan G, Teplow DB, Bowers MT: Amyloid $\beta$-protein: monomer structure and early aggregation states of A 442 and its Pro ${ }^{19}$ alloform. J Am Chem Soc 2005, 127:2075-2084.

72. Funato $\mathrm{H}$, Enya $\mathrm{M}$, Yoshimura $\mathrm{M}$, Morishima-Kawashima $\mathrm{M}$, Ihara Y: Presence of sodium dodecyl sulfate-stable amyloid beta-protein dimers in the hippocampus CA1 not exhibiting neurofibrillary tangle formation. Am J Pathol 1999, 155:23-28.

73. Kuo YM, Emmerling MR, Vigo-Pelfrey C, Kasunic TC, Kirkpatrick JB, Murdoch $\mathrm{GH}$, Ball MJ, Roher AE: Water-soluble Abeta $(\mathrm{N}-40, \mathrm{~N}-42)$ oligomers in normal and Alzheimer disease brains. J Biol Chem 1996, 271:4077-4081.

74. Lambert MP, Viola KL, Chromy BA, Chang L, Morgan TE, Yu J, Venton DL, Krafft GA, Finch CE, Klein WL: Vaccination with soluble Abeta oligomers generates toxicity-neutralizing antibodies. J Neurochem 2001, 79:595-605.

75. Lue LF, Kuo YM, Roher AE, Brachova L, Shen Y, Sue L, Beach T, Kurth JH, Rydel $R E$, Rogers J: Soluble amyloid beta peptide concentration as a predictor of synaptic change in Alzheimer's disease. Am J Pathol 1999, 155:853-862.

76. Yoshiike Y, Minai R, Matsuo Y, Chen YR, Kimura T, Takashima A: Amyloid oligomer conformation in a group of natively folded proteins. PLOS ONE 2008, 3:e3235.

77. Noguchi A, Matsumura S, Dezawa M, Tada M, Yanazawa M, Ito A, Ikioka M, Kikuchi S, Sato M, Ideno S, Noda M, Fukunari A, Muramatsu S, Itokazu Y, Sato K, Takahashi H, Teplow DB, Nabeshima Y, Kakita A, Imahori K, Hoshi M: Isolation and characterization of patient-derived, toxic, high mass amyloid $\beta$-protein (A $\beta$ ) assembly from Alzheimer disease brains. J Biol Chem 2009, 284:32895-32905.

78. Kern A, Behl $\mathrm{C}$ : The unresolved relationship of brain aging and late-onset Alzheimer disease. Biochim Biophys Acta 2009, 1790:1124-1132.

79. El Khoury J, Luster AD: Mechanisms of microglia accumulation in Alzheimer's disease: therapeutic implications. Trends Pharma Sci 2008, 29:626-632. 
80. Ilieva H, Polymenidou M, Cleveland DW: Non-cell autonomous toxicity in neurodegenerative disorders: ALS and beyond. J Cell Biol 2009, 187:761-772.

81. Wogulis M, Wright $\mathrm{S}$, Cunningham D, Chilcote T, Powell K, Rydel RE: Nucleation-dependent polymerization is an essential component of amyloid-mediated neuronal cell death. J Neurosci 2005, 25:1071-1080.

82. Hansen MB, Nielsen SE, Berg K: Re-examination and further development of a precise and rapid dye-method for measuring cell growth/cell kill. $\mathrm{J}$ Immunol Methods 1989, 119:203-210.

83. Hertel C, Hauser N, Schubenel R, Seilheimer B, Kemp JA: $\beta$-amyloid-induced cell toxicity: enhancement of 3-(4,5-dimethylthiazol-2-yl)-2,5diphenyltetrazolium bromide-dependent cell death. J Neurochem 1996, 67:272-276.

84. Kane MD, Schwarz RD, St Pierre L, Watson MD, Emmerling MR, Boxer PA, Walker GK: Inhibitors of V-type ATPases, bafilomycin A1 and concanamycin $A$, protect against beta-amyloid mediated effects on 3(-4,5-dimethylthiazol-2-yl)-2,5-diphenyltetrazolium bromide (MTT) reduction. J Neurochem 1999, 72:1939-1947.

85. Liu Y, Peterson DA, Kimura H, Schubert D: Mechanism of cellular 3-(4,5-dimethylthiazol-2-yl)-2,5-diphenyltetrazolium bromide (MTT) reduction. J Neurochem 1997, 69:581-593.

86. Hu X, Crick SL, Bu G, Frieden C, Pappu RV, Lee J-M: Amyloid seeds formed by cellular uptake, concentration, and aggregation of the amyloid-beta peptide. Proc Natl Acad Sci U S A 2009, 106:20324-20329.

87. Pastor MT, Kümmerer N, Schubert V, Esteras-Chopo A, Dotti CG, López de la Paz M, Serrano L: Amyloid toxicity is independent of polypeptide sequence, length and chirality. J Mol Biol 2008, 375:695-707.

88. Larsen P, Nielsen JL, Dueholm MS, Wetzel R, Otzen D, Nielsen PH: Amyloid adhesins are abundant in natural biofilms. Environ Microbiol 2007, 9:3077-3090.

89. Hepler RW, Grimm KM, Nahas DD, Breese R, Dodson EC, Acton P, Keller PM, Yeager M, Wang H, Shughrue P, Kinney G, Joyce JG: Solution state characterization of Amyloid $\beta$-derived diffusible ligands. Biochemistry 2006, 45:15157-15167.

90. Kumar-Singh S, Julliams A, Nuydens R, Ceuterick C, Labeur C, Serneels S, Vennekens K, Van Osta P, Geerts H, De Strooper B, Van Broeckhoven C: In vitro studies of Flemish, Dutch, and wild-type beta-amyloid provide evidence for two-staged neurotoxicity. Neurobiol Dis 2002, 11:330-340.

91. Price KA, Crouch PJ, Donnelly PS, Masters CL, White AR, Curtain CC: Membrane-targeted strategies for modulating APP and Abeta-mediated toxicity. J Cell Mol Med 2009, 13:249-261.

92. Selkoe DJ: Alzheimer's disease is a synaptic failure. Science 2002 . 298:789-791.

93. Shankar GM, Bloodgood BL, Townsend M, Walsh DM, Selkoe DJ, Sabatini BL: Natural oligomers of the Alzheimer amyloid-beta protein induce reversible synapse loss by modulating an NMDA-type glutamate receptordependent signaling pathway. J Neurosci 2007, 27:2866-2875.

94. Ye C, Walsh DM, Selkoe DJ, Hartley DM: Amyloid beta-protein induced electrophysiological changes are dependent on aggregation state: $\mathrm{N}$-methyl-D-aspartate (NMDA) versus non-NMDA receptor/channel activation. Neurosci Lett 2004, 366:320-325.

95. Laurén J, Gimbel DA, Nygaard HB, Gilbert JW, Strittmatter SM: Cellular prion protein mediates impairment of synaptic plasticity by amyloid-beta oligomers. Nature 2009, 457:1128-1132.

96. Vanhee P, Stricher F, Baeten L, Verschueren E, Lenaerts T, Serrano L, Rousseau F, Schymkowitz J: Protein-peptide interactions adopt the same structural motifs as monomeric protein folds. Structure 2009, 17:1128-1136.

97. Verdier Y, Zarándi M, Penke B: Amyloid $\beta$-peptide interactions with neuronal and glial cell plasma membrane: binding sites and implications for Alzheimer's disease. J Pept Sci 2004, 10:229-248.

98. Bucciantini M, Calloni G, Chiti F, Formigli L, Nosi D, Dobson CM, Stefani M: Prefibrillar amyloid protein aggregates share common features of cytotoxicity. J Biol Chem 2004, 279:31374-31382.

99. Yoshiike Y, Kayed R, Milton SC, Takashima A, Glabe CG: Pore-forming proteins share structural and functional homology with amyloid oligomers. Neuromol Med 2007, 9:270-275.

100. Glabe CG: Structural classification of toxic amyloid oligomers. J Biol Chem 2008, 283:29639-29643.

101. Riek R, Güntert P, Döbeli H, Wipf B, Wüthrich K: NMR studies in aqueous solution fail to identify significant conformational differences between the monomeric forms of two Alzheimer peptides with widely different plaque-competence, $A \beta(1-40)$ (ox) and $A \beta(1-42)(o x)$. Eur J Biochem 2001, 268:5930-5936.

102. Zhang S, Iwata K, Lachenmann MJ, Peng JW, Li S, Stimson ER, Lu Y, Felix AM, Maggio JE, Lee JP: The Alzheimer's peptide a beta adopts a collapsed structure in water. J Struct Biol 2000, 130:130-141.

103. Uversky VN, Gillespie JR, Fink AL: Why are "natively unfolded" proteins unstructured under physiologic conditions? Proteins 2000, 41:415-427.

104. Meredith SC: Protein denaturation and aggregation - cellular responses to denatured and aggregated proteins. Ann NY Acad Sci 2005, 1066:181-221.

105. Margittai M, Langen R: Fibrils with parallel in-register structure constitute a major class of amyloid fibrils: molecular insights from electron paramagnetic resonance spectroscopy. Q Rev Biophys 2008, 41:265-297.

106. Sawaya MR, Sambashivan S, Nelson R, Ivanova MI, Sievers SA, Apostol MI, Thompson MJ, Balbirnie M, Wiltzius JJ, McFarlane HT, Madsen AØ, Riekel C, Eisenberg D: Atomic structures of amyloid cross-beta spines reveal varied steric zippers. Nature 2007, 447:453-457.

107. Walsh DM, Hartley DM, Kusumoto Y, Fezoui Y, Condron MM, Lomakin A, Benedek GB, Selkoe DJ, Teplow DB: Amyloid beta-protein fibrillogenesis. Structure and biological activity of protofibrillar intermediates. J Bio/ Chem 1999, 274:25945-25952.

108. Kirkitadze MD, Condron MM, Teplow DB: Identification and characterization of key kinetic intermediates in amyloid beta-protein fibrillogenesis. J Mol Biol 2001, 312:1103-1119.

109. Klimov DK, Thirumalai D: Dissecting the assembly of $A \beta_{16-22}$ amyloid peptides into antiparallel $\beta$ sheets. Structure 2003, 11:295-307.

110. Nerelius C, Sandegren A, Sargsyan H, Raunak R, Leijonmarck H, Chatterjee U, Fisahn A, Imarisio S, Lomas DA, Crowther DC, Strömberg R, Johansson J: $\alpha$-Helix targeting reduces amyloid- $\beta$ peptide toxicity. Proc Nat/ Acad Sci USA 2009, 106:9191-9196.

111. Soto C, Castaño EM, Frangione B, Inestrosa NC: The a-helical to $\beta$-strand transition in the amino-terminal fragment of the amyloid $\beta$-peptide modulates amyloid fibril formation. J Bio/ Chem 1995, 270:3063-3067.

112. Bouchard M, Zurdo J, Nettleton EJ, Dobson CM, Robinson CV: Formation of insulin amyloid fibrils followed by FTIR simultaneously with CD and electron microscopy. Protein Sci 2000, 9:1960-1967.

113. Mucke L, Masliah E, Yu GQ, Mallory M, Rockenstein EM, Tatsuno G, Hu K, Kholodenko D, Johnson-Wood K, McConlogue L: High-level neuronal expression of abeta 1-42 in wild-type human amyloid protein precursor transgenic mice: synaptotoxicity without plaque formation. J Neurosci 2000, 20:4050-4058.

114. Fezoui Y, Hartley DM, Walsh DM, Selkoe DJ, Osterhout JJ, Teplow DB: A de novo designed helix-turn-helix peptide forms non-toxic amyloid fibrils. Nat Struct Biol 2000, 7:1095-1099

115. Fawzi NL, Yap EH, Okabe Y, Kohlstedt KL, Brown SP, Head-Gordon T: Contrasting disease and nondisease protein aggregation by molecular simulation. Acc Chem Res 2008, 41:1037-1047.

116. Grant MA, Lazo ND, Lomakin A, Condron MM, Arai H, Yamin G, Rigby AC, Teplow DB: Familial Alzhemier's disease mutations alter the stability of the amyloid-beta-protein monomer folding nucleus. Proc Natl Acad Sci U S A 2007, 104:16522-16527.

117. Chacon MA, Barria MI, Soto C, Inestrosa NC: $\beta$-sheet breaker peptide prevents $A \beta$-induced spatial memory impairments with partial reduction of amyloid deposits. Mol Psychiatry 2004, 9:953-961.

118. Kim W, Hecht MH: Sequence determinants of enhanced amyloidogenicity of Alzheimer A 442 peptide relative to A $\beta 40$. J Biol Chem 2005, 280:35069-35076.

119. Permanne B, Adessi C, Saborio GP, Fraga S, Frossard MJ, Van Dorpe J, Dewachter I, Banks WA, Van Leuven F, Soto C: Reduction of amyloid load and cerebral damage in a transgenic mouse model of Alzheimer's disease by treatment with $\beta$-sheet breaker peptide. FASEB J 2002, 16:860-862.

120. Liu R, Barkhordarian H, Emadi S, Park CB, Sierks MR: Trehalose differentially inhibits aggregation and neurotoxicity of beta-amyloid 40 and 42 . Neurobiol Dis 2005, 20:74-81.

121. McLaurin J, Kierstead ME, Brown ME, Hawkes CA, Lambermon MH, Phinney AL, Darabie AA, Cousins JE, French JE, Lan MF, Chen F, Wong SS, Mount HT, Fraser PE, Westaway D, St George-Hyslop P: Cyclohexanehoxol inhibitors of Abeta aggregation prevent and reverse Alzheimer phenotype in a mousemodel. Nat Med 2006, 12:801-808.

122. Nagel-Steger L, Demeler B, Meyer-Zaika W, Hochdörffer K, Schrader T, Willbold D: Modulation of aggregate size- and shape-distributions of the amyloid-beta peptide by a designed beta-sheet breaker. Eur Biophys J 2010, 39:415-422. 
123. Nitz M, Fenili D, Darabie AA, Wu L, Cousins JE, McLaurin J: Modulation of amyloid- $\beta$ aggregation and toxicity by inosose stereoisomers. FEBS J 2008, 275:1663-1674

124. Tjernberg LO, Näslund J, Lindqvist F, Johansson J, Karlström AR, Thyberg J, Terenius $L$, Nordstedt C: Arrest of $\beta$-amyloid fibril formation by a pentapeptide ligand. J Biol Chem 1996, 271:8545-8548.

125. Allured VS, Collier RJ, Carroll SF, McKay DB: Structure of exotoxin A of Pseudomonas aeruginosa at 3.0-angstrom resolution. Proc Natl Acad Sci USA 1986, 83:1320-1324.

126. Blake CC, Oatley SJ: Protein-DNA and protein-hormone interactions in prealbumin: a model of the thyroid hormone nuclear receptor? Nature 1977, 268:115-120

127. Choe S, Bennett MJ, Fujii G, Curmi PM, Kantardjieff KA, Collier RJ, Eisenberg D: The crystal structure of diphtheria toxin. Nature 1992, 357:216-222.

128. Jenner L, Husted L, Thirup S, Sottrup-Jensen L, Nyborg J: Crystal structure of the receptor-binding domain of a2-macroglobulin. Structure 1998, 6:595-604.
129. Louneva N, Cohen JW, Han LY, Talbot K, Wilson RS, Bennett DA, Trojanowski JQ, Arnold SE: Caspase-3 is enriched in postsynaptic densities and increased in Alzheimer's disease. Am J Pathol 2008, 173:1488-1495.

130. Sticht H, Bayer P, Willbold D, Dames S, Hilbich C, Beyreuther K, Frank RW, Rosch P: Structure of amyloid A4-(1-40)-peptide of Alzheimer's disease. Eur J Biochem 1995, 233:293-298.

131. Krieger E, Darden T, Nabuurs S, Finkelstein A, Vriend G: Making optimal use of empirical energy functions: force field parameterization in crystal space. Proteins 2004, 57:678-683.

doi:10.1186/alzrt36

Cite this article as: Broersen $\mathrm{K}$, et al.: The culprit behind amyloid beta peptide related neurotoxicity in Alzheimer's disease: oligomer size or conformation? Alzheimer's Research \& Therapy 2010, 2:12. 